\title{
IDENTIFYING INTERNATIONAL ORGANIZATIONS' CONTRIBUTIONS TO CUSTOM
}

\section{David M. DeBartolo*}

It is widely acknowledged that international organizations (IOs) indirectly affect customary international law by catalyzing and focusing State practice. But next year the International Law Commission and Michael Wood, its Special Rapporteur on the Identification of Customary International Law, are primed to address a more contentious issue: when and how IOs can directly contribute, like States, to custom.

This past summer the Commission's Drafting Committee provisionally adopted a draft conclusion stating that "[i]n certain cases, the practice of international organizations also contributes to the formation, or expression, of rules of customary international law." Based on Wood's Second Report ${ }^{1}$ dated May 2014, three topics merit particular attention in the year ahead: 1) distinguishing State practice from IO practice, 2) scrutinizing potentially relevant types of IO practice, and 3) considering types of cases in which such IO practice might contribute to custom. (While the Drafting Committee declined to include definitions in its draft conclusions, this article defines "IO” as Wood did in his Second Report: “an intergovernmental organization.")

\section{Distinguishing State Practice from IO Practice}

Wood's Second Report is notable for its expansive conception of "practice." Wood rejects the restriction of practice to situations within the domain of international relations, to actual incidents or episodes, and to physical conduct. He endorses, rather, the statement that "the term 'practice' . . . is general enough - thereby corresponding with the flexibility of customary law itself-to cover any act or behaviour of a State," including verbal (written and oral) conduct and including, in certain situations, inaction. The Drafting Committee followed Wood's approach, provisionally adopting draft conclusion 6.1 stating that "[p]ractice may take a wide range of forms" and that it "includes both physical and verbal acts."

This broad interpretation of "practice" makes it particularly important to distinguish State practice that occurs in an IO forum from IO practice. The Drafting Committee's draft conclusion 6.2 provides that forms of State practice include "acts in connection with resolutions of international organizations or international conferences," and Wood wrote in paragraph 41.9 of the Second Report that such acts include "voting in favour or against them (or abstaining), and the explanations (if any) attached to such acts." Other examples of State practice not mentioned by Wood might include a State's engagement in negotiating the substance of such resolutions (e.g., proposals to add or delete particular language), as well as a State's engagement on procedural issues relating to such resolutions (e.g., agenda-setting). (These types of practice may be less visible, yet more revealing, than the State's final vote and its explanation thereof.) Though such acts take place

* Attorney-Adviser in the Office of the Legal Adviser of the Department of State. This article reflects his personal views and may not reflect those of the U.S. Government or the U.S. Department of State.

Originally published online 23 Dec. 2014.

${ }^{1}$ Michael Wood, Special Rapporteur, Second Rep. on Identification of Customary International Law, Int'l Law Comm'n, UN Doc. A/CN.4/672 (May 22, 2014).

ASIL and David M. DeBartolo C 2014 
in an IO forum, they are State acts, carried out by State officials (generally members of a State's delegation or permanent mission to the IO), and as such constitute State practice, not IO practice.

A more practical question is whether and how such State practice should be addressed in the Commission's eventual product. The principal objective of the topic is to offer guidance to those called upon to identify the existence of a rule of customary international law, but it seems unlikely that such practice would often contribute directly to the formation of a rule of customary international law. Acceptance of practice as law is one of the constituent elements for creating a customary rule, but most States negotiate toward and vote for resolutions in IOs for political reasons. It is unlikely that most States view the positions they take in negotiating and voting on IO resolutions as being undertaken out of a sense of legal obligation (with the exception, perhaps, of members of the European Union, who are bound by the Treaty on European Union to put into effect a common foreign and security policy). Accordingly, highlighting such practice seems unlikely to assist readers seeking to identify a rule of customary international law.

A clearer alternative might be to address State acts in connection with resolutions of IOs solely as potential evidence of opinio juris — that is, as potential evidence of the State's acceptance of some other State practice as being authorized or compelled by law. Wood himself refers to such practice in this way in the Second Report's draft conclusion 11.2 on opinio juris.

Types of IO Practice

With respect to IO practice, Wood's Second Report is striking in its focus on IOs' external acts. Wood states in paragraph 43 that "the acts of international organizations on which States have conferred authority may also contribute or attest to the formation of a general practice in the fields in which those organizations operate." He specifies that the relevant practice relates not to the internal affairs of IOs but to their external relations with, e.g., States and other IOs. He describes this practice as consisting mostly of "operational activities," i.e., "the programmatic work of international organizations carried out as part of their overall mission or in fulfilment of a specific mandate."

One might consider several types of IO practice, but this article focuses on three: acts (often resolutions) by IO organs composed of representatives of States (hereinafter "IO intergovernmental organs"), acts by IO secretariats, and acts by IO judicial organs.

\section{Practice of IO Intergovernmental Organs}

In light of the academic attention devoted to the impact of IO intergovernmental organs on customary international law, it will be illuminating to see how Wood approaches the fundamental question of whether an IO intergovernmental organ's practice-a resolution, for example — can contribute more to custom than the sum of the State practice that precedes and follows it.

Wood's Second Report suggests that it can. In paragraph 43 addressing IO practice, Wood states that greater weight is to be given to products of IO intergovernmental organs than to products of IO secretariats, on the grounds that the participants in IO intergovernmental organs (i.e., States) are also the primary authors of State practice. Setting aside IO secretariats for now , the rationale for giving such weight to the products of IO intergovernmental organs as "IO practice" may merit elaboration in the Third Report. It is true that the participants in IOs' intergovernmental organs are also the authors of State practice, but this seems to highlight the difficulty in disentangling IO intergovernmental organ practice from State practice, rather than to resolve the issue. 
One relevant consideration may be any authority States have conferred on the relevant organ. Wood notes in the Second Report that IOs differ in their nature and mandate, which suggests that organizations need not be weighted equally in terms of their contribution to custom. An analogous point could be made with respect to their intergovernmental organs. For example, in the commentary to its Draft Articles on the Responsibility of States for Internationally Wrongful Acts, the Commission cited the Security Council's reaction to Iraq's invasion of Kuwait in 1990 as an example of the practice of non-recognition of acts in breach of peremptory norms. The Security Council's decisions in such situations might be argued to be distinct from (and to add to) State practice underlying them because all UN Member States have conferred on the Council primary responsibility for the maintenance of international peace and security, and have agreed that in carrying out its duties under this responsibility the Council acts on their behalf. By this reasoning a General Assembly resolution on the same topic would not be entitled to similar weight, even though it may reflect the views of more States.

Conceptualizing and identifying opinio juris for the practice of IO intergovernmental organs is also difficult. While one can imagine States' representatives in an IO organ acting out of a sense that the IO has a customary international legal obligation to conduct itself in a particular way, whether that means the organ undertakes the act out of a sense of legal obligation also seems to require disentangling the organ's practice from State practice.

\section{Practice of IO Secretariats}

Because IO secretariats act on behalf of IOs, their practice is less entangled with that of States. And IO secretariats have a wide range of practice within their various spheres of operation. The UN SecretaryGeneral brings claims (per the ICJ Reparations advisory opinion), defends them (e.g., the Haiti cholera claims), and asserts privileges and immunities (as with respect to a Special Rapporteur in response to domestic defamation litigation). The Secretary-General exercises control over UN peacekeeping operations, generating practice between the UN and contributing States, host States, and individuals directly affected by the peacekeepers' conduct. The Director-General of the World Health Organization (WHO) declares Public Health Emergencies of International Concern, as with the ongoing Ebola outbreak, and issues Temporary Recommendations to States; her staff of dedicated international civil servants works with States, IOs, NGOs, multinational corporations and private individuals to provide urgently needed assistance, and in so doing take actions that that affect legal responsibility and liability of the various participants. The Director-General of the International Atomic Energy Agency reports on States' implementation of their nuclear-related obligations.

Such practice is extraordinarily important and unquestionably affects IOs' international legal relationships with other IOs, States, and private individuals and entities. But for it to contribute to the formation or expression of customary international law, one would need to assess whether the practice is (1) widespread and consistent; and (2) whether the necessary opinio juris exists. The reality is that IOs are very different from States; they are created by States pursuant to sui generis constituent instruments, and they do not possess plenary power to act either internally within the organization or externally on the international plane.

It nevertheless seems plausible that it may be easier to identify IO secretariat practice that may be deemed to directly contribute to the formation or expression of custom than to identify such practice by IO intergovernmental organs. In that light, as noted above, Wood states in paragraph 43 of the Second Report that in assessing IO practice greater weight is to be given to products of IO intergovernmental organs than to products of secretariats, on the grounds that the former are also composed of the primary authors of State practice. The Third Report may provide an opportunity for further consideration of this approach. 


\section{Practice of IO Judicial Bodies}

Curiously, the Second Report treats IO judicial bodies such as the International Court of Justice (ICJ) not in its section on IO practice, but rather in a short paragraph on "international courts and tribunals" (paragraph 46) that appears to be part of a section addressing the role of non-State actors other than IOs (paragraph 45). The report does not describe the rationale for treating the ICJ (a principal organ of the UN), and the ICTY and ICTR (Security Council subsidiary organs), together with bodies that have no connection to IOs (such as ad hoc tribunals appointed to arbitrate disputes under bilateral investment treaties). Accordingly, differentiating between IO judicial bodies and tribunals unaffiliated with IOs might open illuminating avenues of inquiry in the Third Report.

One basic question is whether and how an IO judicial body's decision in a contentious case, or an advisory opinion, may contribute to the formulation or expression of a customary rule. The Secretariat's memorandum on the Commission's previous work on customary international law noted the diversity of approaches taken in the past. The Secretariat noted that on some occasions the Commission has relied on decisions of international courts and tribunals as authoritatively expressing the status of a customary rule, that the Commission has often relied on such decisions as one consideration alongside others (e.g., alongside state practice), and that at times the Commission has relied upon such decisions as secondary sources for the purpose of identifying State practice.

Wood seems to endorse the latter approach, writing in paragraph 46 of the Second Report that "decisions of international courts and tribunals as to the existence of rules of customary international law and their formulation are not 'practice,", while stating that "such decisions serve an important role as 'subsidiary means for the determination of rules of law."' It is clearly true that such decisions do not constitute State practice (though they may describe and affect subsequent State practice). But whether decisions by an IO organ like the ICJ could constitute IO practice, in a manner analogous to how decisions of national courts may serve as State practice (as Wood describes in paragraph 41.5 of the Second Report), may merit consideration. If Wood adheres to this approach it will be interesting to observe how he addresses the Commission's past practice and the examples cited therein.

\section{Considering Types of Cases in which IO Practice Could Contribute to Custom}

The disaggregation of the various types of IO practice may help to illuminate the "certain cases" in which the Drafting Committee suggested IO practice contributes to the formation, or expression, of rules of customary international law.

One possibility is that IO practice contributes to custom in relation to IOs' internal affairs. As described above, in the Second Report Wood appears to reject that proposition. He distinguishes in paragraph 43 between "practice relating to the internal affairs of the organization on the one hand, and the practice of the organization in its relations with States, international organizations, etc., on the other," and states that "[i]t is the latter practice that is relevant for present purposes." It remains to be seen whether the next report will also address the former.

Another possibility is that IO practice contributes to the formation and expression of custom when States have transferred certain domestic law competences to the IO, as with the European Union. Wood indicates in paragraph 44 of the Second Report that in such situations IO practice contributes to custom because such organizations" practice "may be equated with that of States, since in particular fields such organizations act in place of the Member States," and notes that if one were to disregard such practice, then such States "would be deprived or reduced of their ability to contribute State practice." But IOs like the EU are rare, and in any 
event, the report suggests IOs like the EU are only a subset of those in which IO practice can contribute to custom.

Conceptually, this raises at least four additional possibilities: when IO practice arises 1) between an IO and nongovernmental individuals/entities unaffiliated with the IO, as in the cases of individuals affected by acts of UN peacekeepers; 2) between IOs and other IOs, such as between the UN and the specialized agencies and related organizations; 3) between IOs and States, as in relations between the UN, States contributing to peacekeeping operations, and States hosting such operations; and 4) between States inter se. A more detailed assessment will need to await Wood's Third Report, but all four raise weighty issues of whether international organizations created by States are subject to-and may contribute to the development of - the customary rules that bind their creators.

At their root are jurisprudential questions about the basis for customary international law-among them whether the underlying basis for such law is exclusively State consent (as positivists would argue) and whether such consent extends to acts by IO actors over which States have no direct control, or whether IOs as international legal persons have as much capacity to contribute to custom as States (as institutionalists might suggest), or whether such law is based on a broader conception of opinio juris as a generally shared legal expectation among humankind. ${ }^{2}$

Wood notes in paragraph 43 of the Second Report that a prominent scholar has suggested that "IOs provide shortcuts to finding custom," to which Wood responds that "considerable caution is required in assessing their practice." Whether or not the types of practice canvassed above provide shortcuts to finding custom, perhaps the Commission's eventual product can do so by clarifying how custom can be identified.

2 See, e.g., Jordan J. Paust, Customary International Law: Its Nature, Sources and Status as Law of the United States, 12 MicH. J. INT'L L. 59, $61(1990)$. 